\title{
THE RESEARCH OF 1,2,4-TRIAZOLE DERIVATIVES HEPATOPROTECTIVE ACTIVITY UNDER TETRACYCLINE AND INFECTIOUS HEPATITIS
}

\author{
TETRASIKLIN VE INFEKSIYYÖZ HEPATIT ŞARTLARI ALTINDA 1,2,4-TRİAZOL \\ TÜREVLERININ KARACI ĞER KORUYUCU AKTIVITELERININ ARAŞTIRILMASI
}

\begin{abstract}
Roman SHCHERBYNA ${ }^{1, *}$, Yevgenia VASHCHYK ${ }^{2}$
${ }^{1}$ Zaporizhzhya State Medical University, Faculty of Pharmacy, Department of Toxicological and Inorganic Chemistry, Zaporizhzhya, Ukraine

${ }^{2}$ Sumy National Agrarian University, Faculty of Veterinary Medicine, Department of Veterinary Sanitary Examination, Microbiology, and Zoohygiene Safety and Quality of Animal Products, Sumy, Ukraine
\end{abstract}

\begin{abstract}
Objective: The purpose of this work is to study the hepatoprotective properties of potassium 2-((4-amino5-(morpholinomethyl)-4H-1,2,4-triazole-3-yl)thio)acetate on tetracycline and infectious hepatitis models in chickens.

Material and Method: Biochemical examination of blood and liver serum was carried out on intact broiler chickens Cross Cobb 500. All groups of chickens were kept separately in different cages in the same room with the same microclimate parameters in accordance with the established requirements.

Result and Discussion: Hepatoprotective effect of potassium 2-((4-amino-5-(morpholinomethyl)-4H1,2,4-triazole-3-yl)thio)acetate was established as a result of research on the model of hepatitis in chickens caused by tetracycline, which was not lower than the referent drug - Thiotriazolin ${ }^{\circledR}$. The biochemical study results demonstrated hepatoprotective properties of the combination of the above compound with the antibiotic Saroflox ${ }^{\circledR}$, combination of potassium 2-((4-amino-5-(morpholinomethyl)-4H-1,2,4-triazole-3-yl) thio) acetate with classical antibiotic Enrofloxacin ${ }^{\circledR}$ on the model of infectious hepatitis.
\end{abstract}

Keywords: biochemical indicators; hepatoprotective activity; 1,2,4-triazole

\footnotetext{
* Corresponding Author / Sorumlu Yazar: Roman Shcherbyna e-mail: rscherbyna@gmail.com

Submitted/Gönderilme: 23.11.2018 Accepted/Kabul: 03.03.2019
} 


\section{ÖZ}

Amaç: Bu çalışmanın amacı tavuklarda oluşturulan tetrasiklin ve infeksiyöz hepatit modellerinde potasyum 2-((4-amino-5-(morfolinometil)-4H-1,2,4-triazol-3-il)tiyo)asetatın karaciğer koruyucu özelliklerini çalışmaktır.

Gereç ve Yöntem: Kan ve karaciğer serumunun biyokimyasal analizi Cobb 500 cinsi să̆lıklı etçi civcivlerde yapılmıştır. Belirlenen koşullara uygun olarak aynı mikroklima parametreleri için tüm civciv grupları aynı oda içinde farklı kafeslerde ayrı olarak tutulmuştur.

Sonuç ve Tartışma: Civcivlerde tetrasiklin ile oluşturulan hepatit modelindeki çalışmanın sonucu olarak potasyum 2-((4-amino-5- (morfolinometil)-4H-1,2,4-triazol-3-il)tio)asetat'ın belirlenen karaciğer koruyucu etkileri referans ilaç olan Thiotriazolin'den daha aşağıda bulunmamıştır. Biyokimyasal çalışmanın sonuçları, yukarıda belirtilen bileşiğin Saroflox antibiyotik ile kombinasyonunun, klasik antibiyotik Enrofloxacin ile potasyum 2-((4-amino-5- (morfolinometil)-4H-1,2,4-triazol-3-il)tio)asetat'in kombinasyonunun karaciğer koruyucu özelliklerini göstermektedir.

Anahtar Kelimeler: biyokimyasal belirteçler; karaciğer koruyucu aktivite; 1,2,4-triazol

\section{INTRODUCTION}

According to the latest reports of the World Health Organization (WHO), hepatitis has a significant threat to human health worldwide [1]. So, viral hepatitis has caused 1.34 million deaths in 2015. This figure is comparable with tuberculosis and higher than that caused by HIV. However, the threat is that the number of deaths due to viral hepatitis increases over time, while mortality caused by tuberculosis and HIV is reduced and actively monitored. Most deaths caused by viral hepatitis in 2015 were associated with chronic liver disease (720,000 deaths due to cirrhosis) and primary liver cancer (470,000 deaths due to hepatocellular carcinoma). Worldwide, in 2015, approximately 257 million people lived with chronic hepatitis B virus (HBV) infection and 71 million people with chronic hepatitis $\mathrm{C}$ virus (HCV) infection 1 . Therefore, this problem is very topical and it is sharply stands before medicine and pharmacy in general [2-5].

Analyzing the scientific literature in this direction, it can be noted that scientists share basically two ways of creating new hepatoprotectors. Quite promising results are obtained in phytochemicals that use medicinal raw materials as the basis for new drugs [6, 7]. Synthetic chemists also actively work in this direction, and this gives its results [8-10]. The synthetic hepatoprotector Thiotriazolin ${ }^{\circledR}$ (Morpholine 5-methyl-1,2,4-triazoline-5-thioacetate) is intruded in the pharmaceutical industry which according to the chemical structure is a nitrogen-containing heterocycle, derivative of 1,2,4-triazole [11]. It is important that the derivatives of 1,2,4-triazole are pharmacologically valuable objects. The novelty is Trifuzol ${ }^{\circledR}$ (Piperidine 2-(5-(furan-2-yl)-4H-4-phenyl-1,2,4-triazole-3-ylthio)acetate) which is introduced in veterinary practice [12].

In turn, in our previous studies, the compound of potassium 2-((4-amino-5(morpholinomethyl)-4H-1,2,4-triazole-3-yl)thio)acetate, which is also a representative of the above noted class of 1,2,4-triazoles. This compound is interesting because, along with its low toxicity, it can exhibit antioxidant properties [13]. The goal of this work is to study hepatoprotective properties of 
potassium 2-((4-amino-5-(morpholinomethyl)-4H-1,2,4-triazole-3-yl)thio)acetate on tetracycline and infectious (Pseudomonas aeruginosa) models of hepatitis in chickens.

\section{MATERIAL AND METHOD}

\section{Animals}

Biochemical examination of blood and liver serum was performed on inbred broiler chickens Cross Cobb 500. All groups of chickens were kept separately in different cages in one room with the same microclimate parameters in accordance with the established requirements. Feeding was carried out with same batch and age of combined feed, drinking - with boiled water. The approval of the Animal Ethics Committee was obtained.

\section{Chemicals}

The main substance of potassium 2-((4-amino-5-(morpholinomethyl)-4H-1,2,4-triazole-3yl)thio)acetate was synthesized at the Department of Toxicological and Inorganic Chemistry of Zaporizhzhya State Medical University. It was purified by recrystallization with content of the main component $\geq 98 \%$. Medicinal products used in the study: Tetracycline Hydrochloride ${ }^{\circledR}$ (Borshchahivskiy CPP, Ukraine), Enrofloxacin ${ }^{\circledR}$ (Basalt, Ukraine), Saroflox ${ }^{\circledR}$ (Brovapharma, Ukraine), Thiotriazolin $^{\circledR}$ (Arterium, Ukraine) and chemical reagents: 2-thiobarbituric acid ( $\left.\geq 98 \%\right)$ and 5,5dithio-bis-(2-nitrobenzoic acid) (DTNB, Ellman's Reagent) supplied from Sigma-Aldrich (Germany). Modeling of Tetracycline Hepatitis

Biochemical study of blood serum and liver was conducted at intact chickens (Intact group); chickens that have been given tetracycline (Control Pathology); chickens, which were injected with a potassium 2-((4-amino-5-(morpholinomethyl)-4H-1,2,4-triazole-3-yl)thio)acetate or Thiotriazolin compound for preventive and therapeutic purposes.

Tetracycline was administered per os to all chickens in experimental groups at a dose of 500 $\mathrm{mg} / \mathrm{kg}$ in the form of suspension of $1 \%$ starch glidant for 5 days. Potassium 2-((4-amino-5(morpholinomethyl)-4H-1,2,4-triazole-3-yl)thio)acetate and Thiotriazolin were injected per os 3 days before Tetracycline, during all period of Tetracycline intake and in the next 2 days 1 hour before tetracycline intake of $150 \mathrm{mg} / \mathrm{kg}$ and $50 \mathrm{mg} / \mathrm{kg}$ appropriately. Three days after the last administration of Tetracycline, blood samples and liver samples were collected from chickens in each experimental group.

\section{Modeling of Infectious Hepatitis}

Biochemical study of blood serum and liver of intact chickens (Intact group); chickens infected with the strain of Pseudomonas aeruginosa (Control Pathology); chickens which were administered with the potassium 2-((4-amino-5-(morpholinomethyl)-4H-1,2,4-triazole-3-yl)thio)acetate for preventive-curative purpose with a classical antibiotic Enrofloxacin or with antibiotic Saroflox, or administered Thiotriazolin with an antibiotic Enrofloxacin. 
Chickens of experimental groups were intraperitoneally injected with Pseudomonas aeruginosa in a dose of $0.2 \mathrm{ml}$ for a 4 day trial in the dilution of 300,000 CFU/ml. Potassium 2-((4-amino-5(morpholinomethyl)-4H-1,2,4-triazole-3-yl)thio)acetate and Thiotriazolin were injected per os for 3 days before infection and for 5 days after infection at a dose of $150 \mathrm{mg} / \mathrm{kg}$ and $50 \mathrm{mg} / \mathrm{kg}$ appropriately. Antibiotics were administered within 5 days after infection.

Sampling of blood and liver in the chickens of each experimental group was carried out 6 days after infection.

\section{Biochemical indicators}

The physiological condition of the liver was evaluated by the activity of the alanine and aspartate aminotransferase (ALT, AST) hepatic enzymes and gammaglutamyltranspeptidase (GGT) in the serum according to the guideline. The status of lipid peroxidation processes and antioxidant defense systems was determined by the content of products that react with tiobarbituric acid (TBA) [14-16] and catalase activity [17-18].

By means of biochemical analysis methods in blood serum and liver homogenates, indicators were determined that generally characterize the balance of the prooxidation and antioxidant systems responsible for the condition of the of free radical oxidation (FRO) process. The content of primary and secondary lipid peroxidation products: conjugated dienes and products that react with tiobarbituric acid (TBA) were determined. The mentioned metabolites are sequentially formed on the path of free transformation of unsaturated fatty acids of membrane phospholipids and their simultaneous determination gives an idea of the severity of membrane destruction. The method for determining the content of conjugated dienes (CD) is based on the ability of conjugated diene acyls and their hydroxy derivatives to intensive uptake in the interval of 232-233 nm. Calculation of the concentration of conjugated dienes was carried out by according to the next formula:

$$
C=\frac{\text { Esample }}{22,727(\text { umol/l) }}
$$

where, $\quad$ C - the concentration of the appropriate product LOP, $\mathbf{E}_{\text {sample - optical density of the sample, }}$

E - molar extinction coefficient.

The content of TBA in blood serum and liver homogenates was determined by a colorimetric method based on the formation of a colored trimethicone malondialdehyde complex (MDA) with thiobarbituric acid, having a maximum absorption at $532 \mathrm{~nm}$. The calculation of the concentration of $\mathrm{CD}$ was carried out according to the formula: 


$$
C=\frac{\text { Esample }}{12,86(\mathrm{umol} / \mathrm{l})}
$$

$$
\begin{aligned}
& \text { where, } \quad \mathbf{C} \text { - the concentration of the appropriate product LOP, } \\
& \mathbf{E}_{\text {sample - optical density of the sample, }} \\
& \mathbf{E} \text { - molar extinction coefficient. }
\end{aligned}
$$

The condition of antioxidant system (AOS) was evaluated by the content of reduced glutathione (GSH) and activity of catalase antioxidant protection enzyme (Cat) in blood and liver homogenates. The principle of the method for determining the content of GSH is based on the ability of low molecular weight thiol compounds at interacting with DTNB (5,5-dithio-bis-(2-nitrobenzoic acid)) to form a colored compound - thio-2-nitrobenzoic acid, the aqueous solution of which has a maximum absorption at $\lambda=412 \mathrm{~nm}$.

The activity of Cat was evaluated by the method of Korolyuk et al [19]. The basis of the method is the ability of hydrogen peroxide to form a stable colored complex with molybdenum salts. Extinction was measured on UV-26 at a wavelength of $410 \mathrm{~nm}$ against a control sample, in which $2 \mathrm{ml}$ of water was introduced instead of peroxide. The calculation was carried out according to the formula:

$$
\begin{aligned}
& \text { Catalase activity }=\frac{\text { Acontrol }- \text { Aexperimental }}{\boldsymbol{V} \cdot \boldsymbol{t} \cdot \boldsymbol{K}(\mu \mathrm{mol} / \mathrm{min} \cdot \mathrm{l})} \\
& \text { where, } \quad \begin{aligned}
\mathbf{V} \text { - volume of the administered sample }(0,1 \mathrm{ml}), \\
\mathbf{t} \text { - incubation time }(600 \mathrm{sec}), \\
\\
\mathbf{K}-\text { coefficient of millimolar extinction of hydrogen peroxide } \\
\left(22,2 \cdot 10^{3} \mathrm{mmol}^{-1} \mathrm{~cm}^{-1}\right)
\end{aligned}
\end{aligned}
$$

\section{Statistical Analysis}

The statistical analysis of the results was carried out using the methods of variation statistics using the STATISTICA program, V.6. For multiple comparisons of data with normal distribution, the Newman-Keuls method was used, the data represented both the mean (M) and the mean error (m). Differences were considered statistically significant at $\mathrm{p}<0.05[20]$. 


\section{RESULT AND DISCUSSION}

The research results of hepatoprotective activity of potassium 2-((4-amino-5(morpholinomethyl)-4H-1,2,4-triazole-3-yl)thio)acetate against the backdrop of tetracycline hepatitis are shown in Figure 1, 2. As the studies showed, administration of tetracycline resulted in a significant damage to the liver. The statistically significant increase in marker enzymes of cytolysis ALT and AST by $36 \%$ and $28 \%$ indicated the development of cytolytic processes. However, the activity of the enzyme GGT has not changed significantly (Fig. 1). In addition, there was an imbalance in the LOP/AOS system, as evidenced by a tendency to increase the TBA content and a statistically significant decrease in the activity of the enzyme antioxidant protection of catalase in 1, 2 times (Fig. 1).

Preventive and therapeutic administration of potassium 2-((4-amino-5- (morpholinomethyl)4H-1,2,4-triazole-3-yl)thio)acetate and Thiotriazolin prevents the development of the cytolytic syndrome and restores the balance of antioxidant processes (Fig. 1). The activity of the liver transaminases and GGT decreased, the content of secondary LOP products decreased and the activity of catalase was restored both in serum and in the liver of chickens (Fig. 1, 2). Also, for this model of hepatitis pathology a histological study was conducted [21].

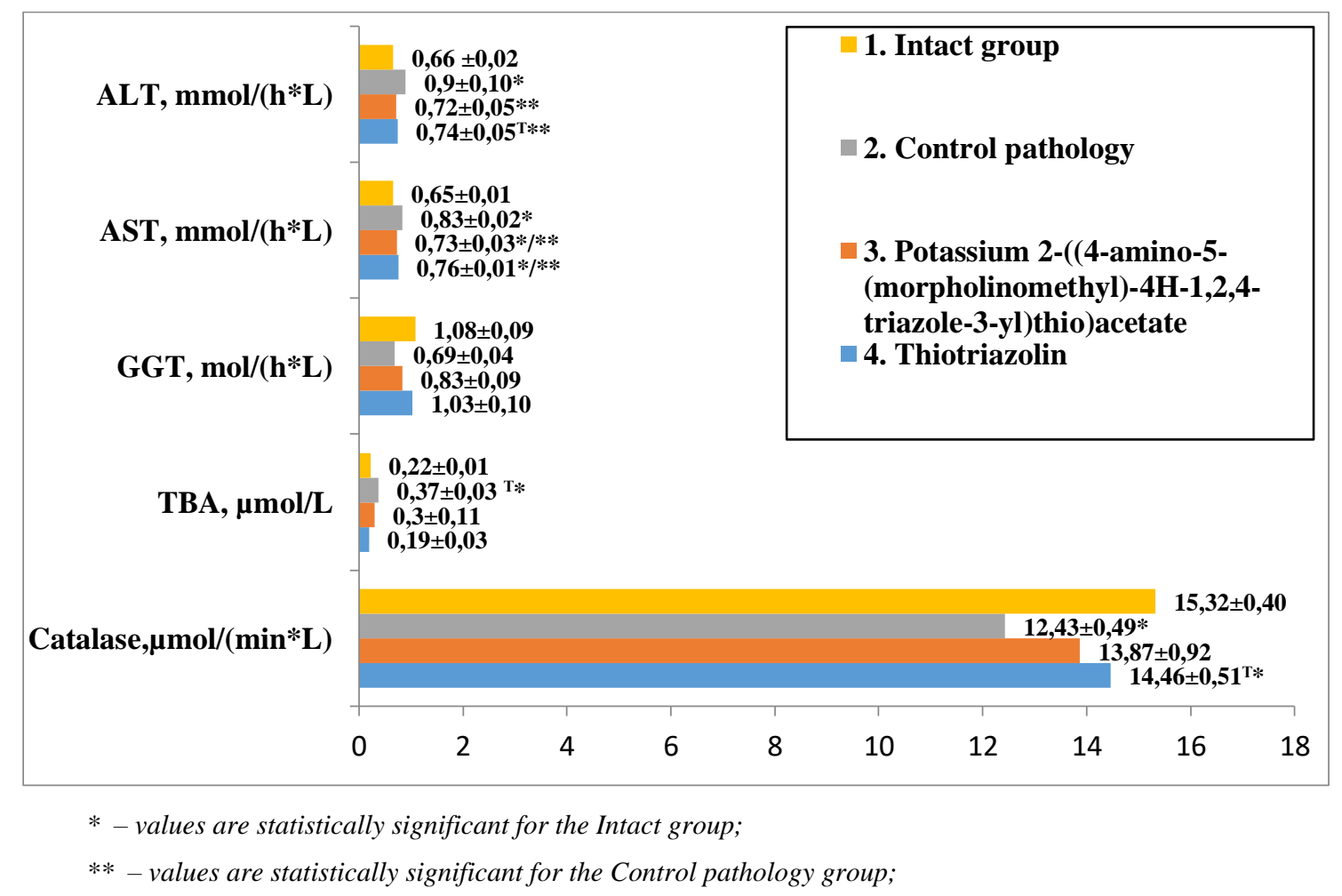

Figure 1. Influence of potassium 2-((4-amino-5-(morpholinomethyl)-4H-1,2,4-triazole-3yl)thio)acetate solution on the biochemical parameters of chicken blood serum on tetracycline-induced hepatitis 


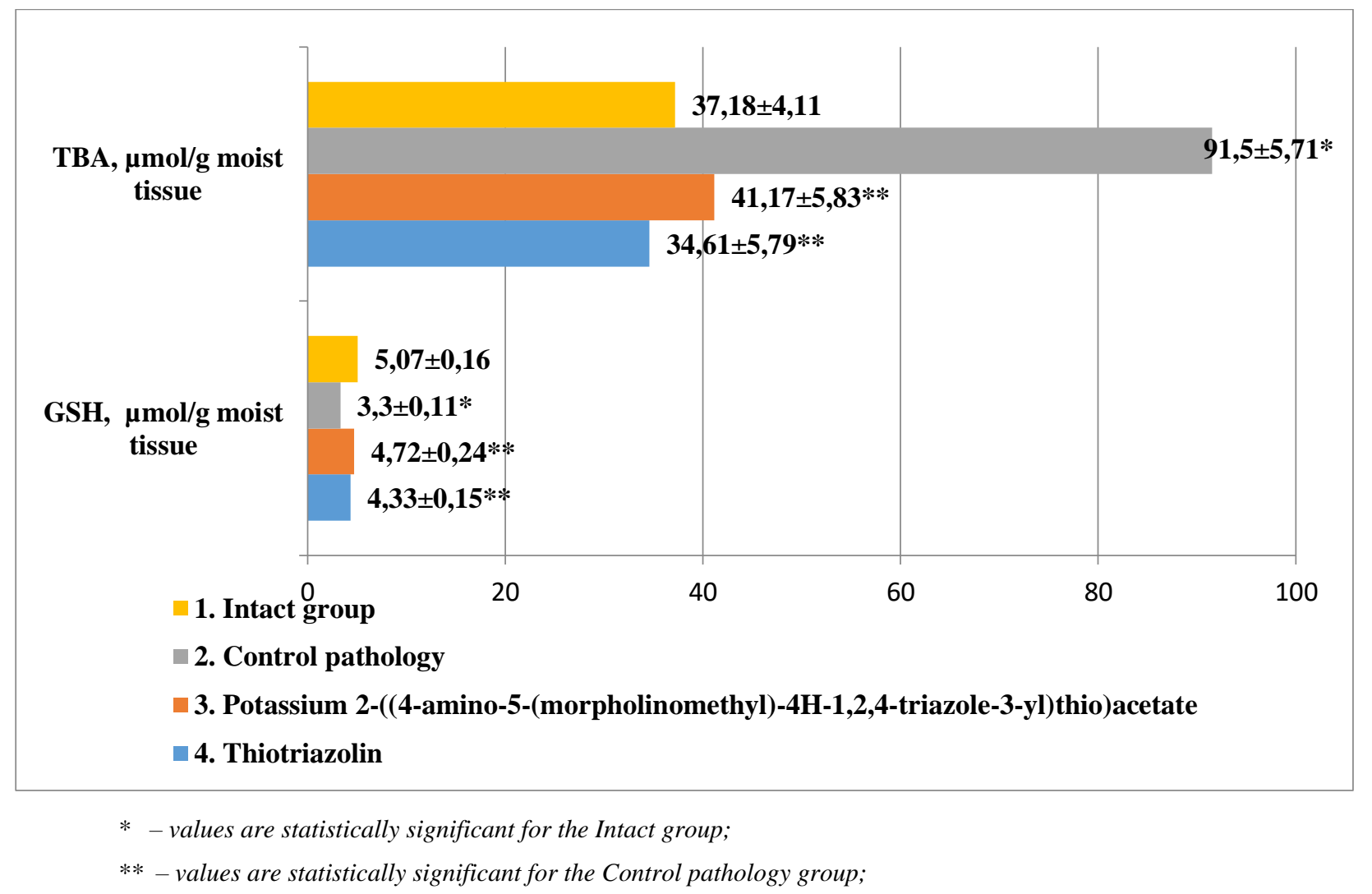

Figure 2. Influence of potassium 2-((4-amino-5-(morpholinomethyl)-4H-1,2,4-triazole-3yl)thio)acetate on the TBA and GSH indices in chicken liver homogenates on tetracycline-induced hepatitis.

Subsequently, the studying of hepatoprotective properties of potassium 2-((4-amino-5(morpholinomethyl)-4H-1,2,4-triazole-3-yl)thio)acetate in the conditions of infectious hepatitis was continued. Infection of the Pseudomonas aeruginosa in chickens led to liver damage. The statistically significant increase in ALT and AST activity by $47 \%$ and 36\%, respectively, indicated the development of a cytolytic syndrome against the background of infection with Pseudomonas aeruginosa. The increase of the most specific hepatic enzyme GGT only tended to increase (Fig.3). Along with this, activation of peroxide lipid oxidation and reduction of antioxidant defense activity were observed: the TBA content was increased by almost 2 times, and the catalase activity decreased by 1.5 times (Fig. 3, 4).

According to the obtained data, the potassium 2-((4-amino-5-(morpholinomethyl)-4H-1,2,4triazole-3-yl)thio)acetate in combination with different antibiotics and a combination of Thiotriazolin and antibiotics possess with expressive hepatoprotective properties (Fig. 3.4). All three combinations effectively prevented the development of the cytolytic syndrome and eliminated the imbalance in the LOP/AOS system in serum and in the liver homogenates (Fig. 3-5). 


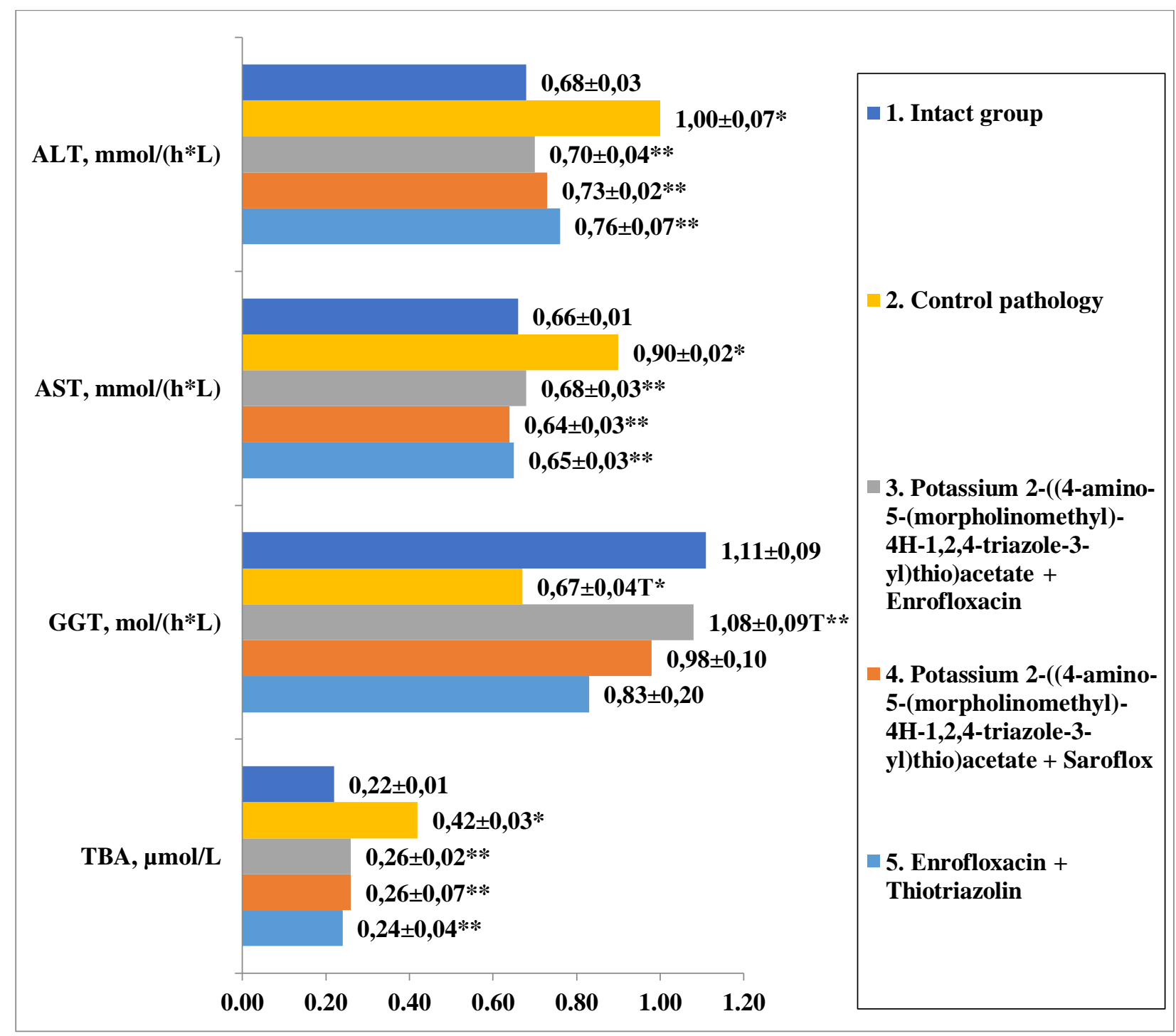

* - values are statistically significant for the Intact group;

** - values are statistically significant for the Control pathology group;

Figure 3. Influence of potassium 2-((4-amino-5-(morpholinomethyl)-4H-1,2,4-triazole-3yl)thio)acetate on the biochemical parameters of blood serum and chicken liver on the model of hepatitis induced by Pseudomonas aeruginosa microorganisms, $\mathrm{M} \pm \mathrm{m}$ 


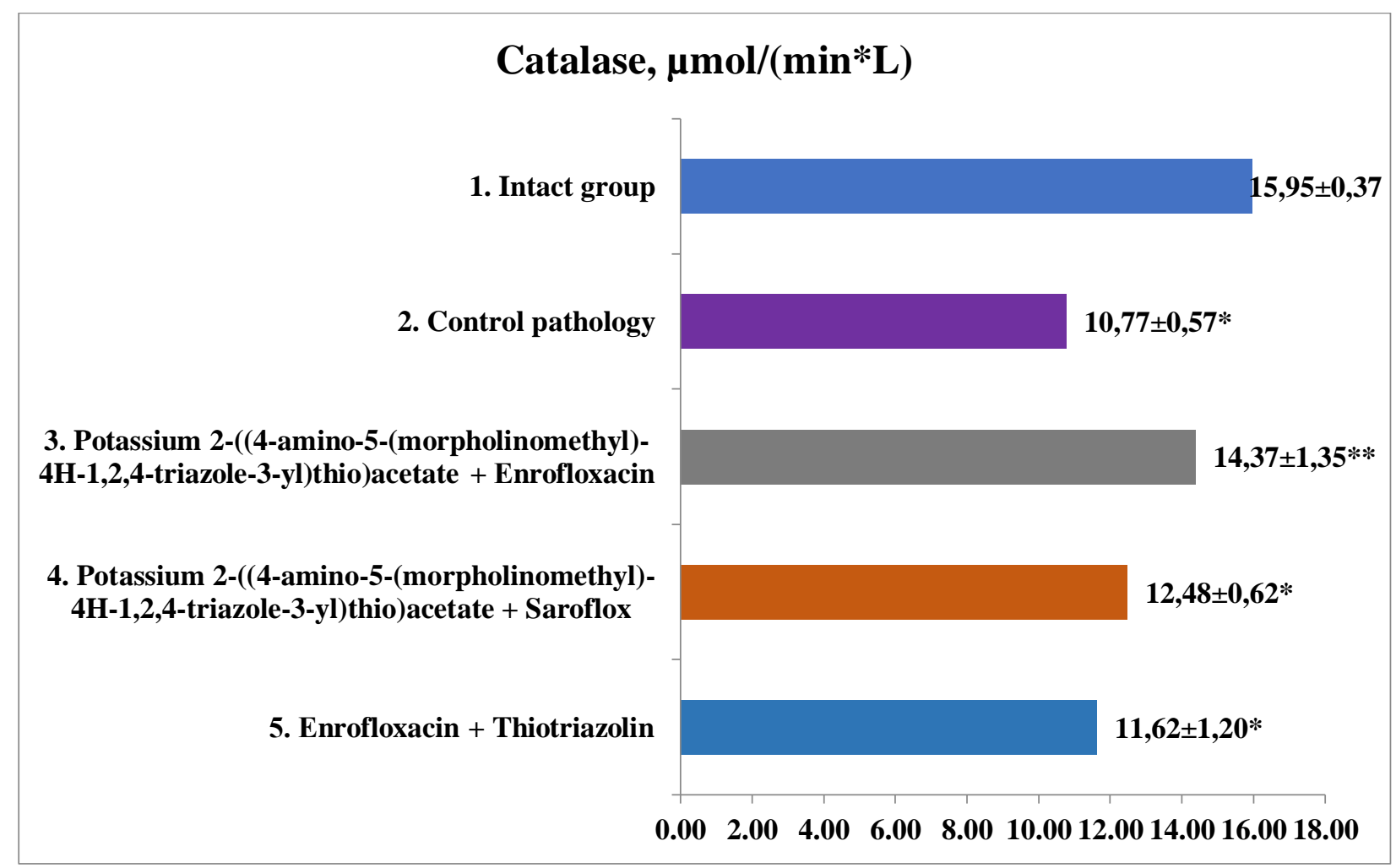

* - - values are statistically significant for the Intact group;

** - values are statistically significant for the Control pathology group;

Figure 4. Influence of potassium 2-((4-amino-5-(morpholinomethyl)-4H-1,2,4-triazole-3yl)thio)acetate on the indices of catalase in blood serum and chicken liver on a model of hepatitis induced by Pseudomonas aeruginosa microorganisms, $\mathrm{M} \pm \mathrm{m}$ 


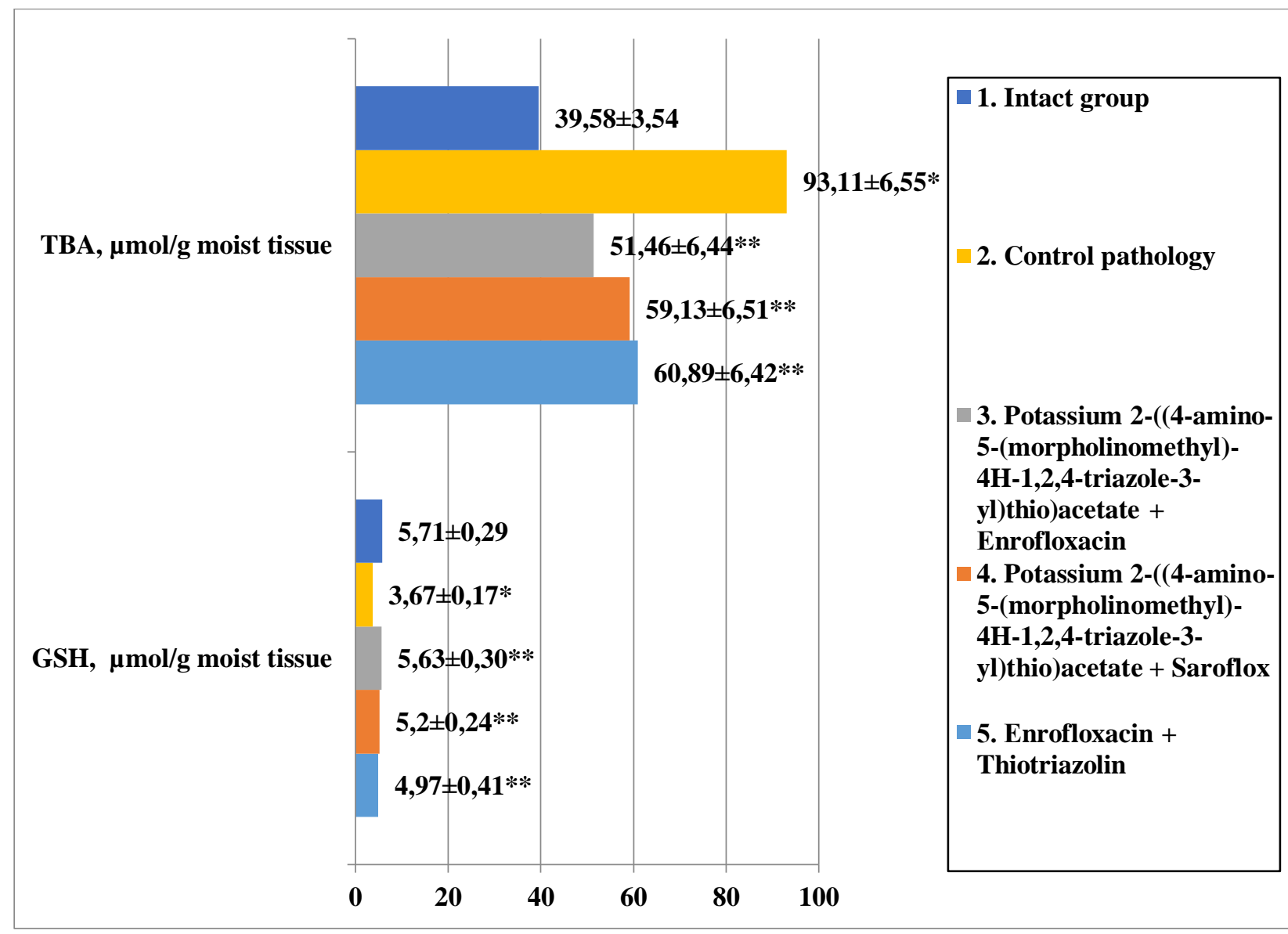

* - - values are statistically significant for the Intact group;

** - values are statistically significant for the Control pathology group;

Figure 5. Influence of potassium 2-((4-amino-5-(morpholinomethyl)-4H-1,2,4-triazole-3yl)thio)acetate on the TBA and GSH indices in chicken liver homogenates on the hepatic model induced by Pseudomonas aeruginosa microorganisms, $\mathrm{M} \pm \mathrm{m}$

As a result of the study it should be noted that potassium 2-((4-amino-5-(morpholinomethyl)4H-1,2,4-triazole-3-yl)thio)acetate express hepatoprotective effect in chickens with the hepatitis caused by tetracycline, and this effect is not inferior to the comparator Thiotriazolin. Based on the results of the biochemical study, hepatoprotective properties were established of the combination of the above compound with the antibiotic Saroflox, combination of potassium 2-((4-amino-5-(morpholinomethyl)4H-1,2,4-triazole-3-yl)thio)acetate with classical antibiotic Enrofloxacin on the model of infectious hepatitis (Pseudomonas aeruginosa).

\section{REFERENCES}

1. World Health Organization. (2017). Global hepatitis report 2017. World Health Organization.

2. Popovich, V.P. (2011). Research of the Range of Hepatoprotectors in the Pharmaceutical Market of Ukraine. Pharmacology and Drug Toxicology, 1(20), 75-81. 
3. Popovich, V.P., Gromovik, B.P., Glukhovsky, P.V. (2012). Market segment of hepatoprotectors in group and individual measurements. Pharmacology and Drug Toxicology, 1(26), $72-76$.

4. Reyes-Arellano, A., Gómez-García, O., Torres-Jaramillo, J. (2016). Synthesis of Azolines and Imidazoles and their Use in Drug Design. Med. Chem.(Los Angeles), 6, 561-570.

5. Rud, A.M., Kaplaushenko, A.G., Pruglo, E.S., Frolova, Y.S. (2017). Hepatoprotective activity of 1, 2, 4-triazole-3-thione derivatives, which contains on C5-atomic carbon hydroxy (phenyl) methyl dependent. Farmatsevtychnyi zhurnal, (5-6), 55-63.

6. Mohammed, G.J., Hameed, I.H. (2018). Pharmacological Activities: Hepatoprotective, Cardio Protective, Anti-cancer and Anti-Microbial Activity of (Raphanus Raphanistrum Subsp. Sativus): A review. Indian Journal of Public Health, 9(3), 212-217.

7. Udom, G.J., Yemitan, O.K., Umoh, E.E., Mbagwu, H.O., Ukpe, E.E., Thomas, P.S. (2018). Hepatoprotective Properties of Ethanol Seed Extract of Citrus paradisi Macfad (Grape Fruit) Against Paracetamol-Induced Hepatotoxicity in Wistar Rats. Journal of Herbal Drugs (An International Journal on Medicinal Herbs), 8(4), 219-227.

8. Mari, G., Catalani, S., Antonini, E., De Crescentini, L., Mantellini, F., Santeusanio, S., Palma, F. (2018). Synthesis and biological evaluation of novel heteroring-annulated pyrrolinotetrahydroberberine analogues as antioxidant agents. Bioorganic \& medicinal chemistry, 26(18), 5037-5044.

9. Vyshtakalyuk, A.B., Nazarov, N.G., Zobov, V.V., Abdulkhakov, S.R., Minnekhanova, O.A., Semenov, V.E., Reznik, V.S. (2017). Evaluation of the hepatoprotective effect of L-ascorbate 1-(2-hydroxyethyl)-4, 6-dimethyl-1, 2-dihydropyrimidine-2-one upon exposure to carbon tetrachloride. Bulletin of experimental biology and medicine, 162(3), 340-342.

10. Sachdeva, M., Chadha, R., Kumar, A., Karan, M., Singh, T., Dhingra, S. (2015). Hepatoprotective effect of trimethylgallic acid esters against carbon tetrachloride-induced liver injury in rats. Hepatoprotective effect of trimethylgallic acid esters against carbon tetrachlorideinduced liver injury in rats. Indian Journal of Experimental Biology,53, 803-809.

11. Tiotriazolin ${ }^{\circledR}$ tablets - instructions, analogues, composition, indications, reviews. Arterium Corporation. Reference http://compendium.com.ua/info/7043/tiotriazolin-sup-sup-. Published 2018. Accessed November 20, 2018.

12. Bushueva, I., Parchenko, V., Shcherbyna, R., Safonov, A., Kaplaushenko, A., Gutyj, B., Hariv, I. (2017). Tryfuzol-new original veterinary drug. Ankara Üniversitesi Eczacilık Fakültesi Dergisi, 41(1), 42-49.

13. Shcherbyna, R.O., Panasenko, O.I., \& Knysh, Y.H. (2016). The studying of antioxidant activity of salts 2-((4-R-3-(morpholinomethylen)-4H-1, 2, 4-triazole-5-yl)thio)acetic acids. Ukraïns' kij bìofarmacevtičnij žurnal, 1 (42), 37-48.

14. Stalnaya, I.D., Garishvili, T.G. (1977). Method for the Determination of Malonic Dialdehyde Using Thiobarbituric Acid. Modern methods in biochemistry, 66-68.

15. Lutsik, B.D. (2011). Clinical laboratory diagnostics. Medicine: Kiev. 
16. Burtis, C.A., Ashwood, E.R., Bruns, D.E. (2012). Tietz textbook of clinical chemistry and molecular diagnostics-e-book. Elsevier Health Sciences.

17. Dembińska-Kieć, A., Naskalski, J., Solnica, B. (2017). Diagnostyka laboratoryjna z elementami biochemii klinicznej, Edra Urban \& Partner, Wrocław, p. 909.

18. Beutler, E.D., Duron Q., Kelly B.M. (1963). A Colorimetric Method for the Determination of Serium Glutamic Oxalatic and Glutaminic Pynovic Transaminases. Journal Laboratories Clinical Medicine, 61, 882.

19. Korolyuk, M.A., Ivanova, L.K., Mayorova, I.G., Tokareva, V.A. (1988). Method For The Determination of Catalase Activity. Clinical laboratory diagnosis, 4, 44-47.

20. Khalafyan, A.A. (2007). Statistica 6. Statistical Data Analysis. Textbook; Binom-Press: Moskow.

21. Shcherbyna, R.O., Vashchyk, Y.V. (2018). Histological study of potassium 2-((4-amino-5(morpholinomethyl)-4H-1, 2, 4-triazole-3-yl)thio)acetate (PKR-173) corrective influence on the chickens liver state in the condition of tetracycline hepatitis. Zaporožskij Medicinskij Žurnal, 3, 404-412. 